\title{
Investment and labor income shares
}

\author{
Georgios Chortareas ${ }^{1,3,4} \cdot$ Emmanouil Noikokyris ${ }^{2,4}$
}

Received: 28 September 2019 / Accepted: 6 February 2020 / Published online: 5 March 2020

(c) The Author(s) 2020

\begin{abstract}
We explore empirically the determinants of labor shares focusing on the role of investment. We use a cross-country framework and consider up to 99 countries for the period 2004-2015. Our results reveal that the level of a country's investment is a significant driving factor of the labor share of income. This evidence is in line with the predictions of neoclassical mechanisms for the role of investment in labor share. Among several other factors that we consider, as suggested by the extant empirical literature, we find strong evidence only for the degree of a country's exposure to the international financial system, which is inversely related to the labor shares. Moreover, economic freedom amplifies the positive effect of gross fixed capital formation on labor income shares.
\end{abstract}

Keywords Labor share $\cdot$ Capital formation $\cdot R \& D$ expenses

JEL Classification E22 - E25 · F66

Georgios Chortareas

georgios.chortareas@kcl.ac.uk; gchortar@econ.uoa.gr

Emmanouil Noikokyris

E.Noikokyris@kingston.ac.uk

1 Economics Group, King's Business School, King's College London, Bush House, 30 Aldwych, London WC2 B4BG, UK

2 Department of Accounting, Finance and Informatics, Kingston University London, Kingston upon Thames KT2 7LB, UK

3 Department of Economics, National and Kapodistrian University of Athens, 1 Sophocleous Street, 10559 Athens, Greece

4 Centre for Data Analytics for Finance and Macroeconomics, King's Business School, King's College London, Bush House, 30 Aldwych, London WC2 B4BG, UK 


\section{Introduction}

One of Kaldor's (1957) "stylized facts" is the constancy of the income distribution between the two key factors of production, capital and labor. The reported decline in the labor share of income since the early 1980s (see, for example, Karabarbounis and Neiman 2014; Elsby et al. 2013), however, has challenged this perception and renewed the interest in the factor shares. The declining amount of income accruing to labor translates to rising income inequality on the premise that profits are less equally distributed than wages (Piketty 2014). Jacobson and Occhino (2012), in fact, provide numerical estimates for the increase in the US Gini index attributed to the decline in labor income share. Atkinson (2009) advocates the importance of studying factor shares drawing upon arguments about interpersonal income inequality, social justice and the proper tax treatment of different sources of income. Against this background, several attempts have been made to empirically establish the determinants of the labor share of income (see, among others, Stockhammer 2017; Furceri and Loungani 2018). Lawrence (2015) offers an alternative explanation of the declining labor income share, relying on neoclassical considerations. Lawrence (2015) shows that in the USA, the combination of a relatively low elasticity of substitution between capital and labor $(\sigma<1)$ and "labor-augmenting" technical change can explain the declining labor/capital ratio. One implication is that higher capital formation will raise labor income shares. Laurence (2015) uses sectoral data from the USA to show that low elasticities of substitution and the decline in the effective capital/labor ratio can account for much of the decline in labor's share in the USA. In the neoclassical paradigm, the elasticity of substitution between capital and labor determines the way in which income is distributed between the two factors of production. ${ }^{1}$ Thus, under specific assumptions about the elasticities between capital and labor of different skill levels, technological innovations that are capital augmenting (i.e., the marginal product of capital is higher than the marginal product of labor) induce firms to substitute labor with capital, and the labor's share of income falls. Guerriero and Sen (2012) provide evidence on the relationship between investment and the functional distribution of income, and report, for some of the specifications employed, a "puzzling" positive relationship for the developing countries.

The present paper produces international evidence to characterize empirically the implications of capital formation for the total amount of income accruing to labor. We provide panel estimations of labor share growth on investment and on a set of theoretically motivated control variables that emerge in the literature as important determinants of income's functional distribution between labor and capital. The control variables aim to capture technological change, real and financial globalization, the size of welfare state, workers' bargaining power and human capital. We use a panel framework that includes up to 99 countries, advanced and emerging, covering the period from 2004 to 2015.

\footnotetext{
${ }^{1}$ See, for example, Lawrence (2015) for a detailed description.
} 
The existing empirical evidence on the role of technology in labor share decline is mixed. Karabarbounis and Neiman (2014), for instance, use calibration methods and find that the higher capital/labor ratios, as a consequence of technologically induced lower relative investment prices, account for almost half of the decline in labor income share. IMF (2007) using data from 18 OECD countries also provides empirical evidence, showing that the effects of technological progress on the labor share can be negative. Stockhammer (2017), on the contrary, does not find evidence that technological change, measured by the logarithm of the GDP per worker, is an important factor driving labor shares. Instead, a small positive impact of technological change on the labor income share emerges in developing countries. Guerriero and Sen (2012) report a positive relationship between technology, proxied either by the number of patent applications or the expenses on research and development (R\&D), and labor share.

The level of workers' educational attainment is customarily considered an important moderating factor for the relationship between technological progress and labor's income share. Skilled labor is commonly considered to exhibit lower substitutability/complementarity with capital (Elsby et al. 2013; Lawrence 2015). This motivates the inclusion of human capital as a factor that might explain the functional distribution of income. Existing evidence from Guerriero and Sen (2012) suggests that human capital, proxied by the number of years in schooling, increases labor income share only in OECD economies, while it does not seem to be a significant factor for the developing ones.

Another factor, which might account for the recent decline in labor's share of output, is the deterioration of labor's bargaining power compared to capital. For example, Guschanski and Özlem (2018), in addition to the role of technological change, consider workers' bargaining power and globalization. The globalization argument suggests that the bargaining power of employees is thwarted by higher real and financial integration with the world. Focusing on the role of trade openness, the empirical evidence on this matter is mixed. There is, for instance, cross-country empirical evidence that trade openness is associated with lower labor income share (Harrison 2005; Dünhaupt 2017). Nevertheless, Guerriero and Sen (2012) in their cross-country study using data from 89 countries find a positive relationship between trade openness and labor share, especially for developing countries.

An extant literature also focuses on the impact of financial globalization on labor income shares. Elsby et al. (2013), for example, identify offshoring to be the most reliable explanation for the reported decline in the US labor income share. The literature employs several proxies for a country's degree of financial integration. Furceri and Loungani (2018) use a de jure measure of capital account openness, Jayadev (2007) constructs an index measuring capital account openness, Stockhammer (2017) uses the total amount of foreign assets and liabilities as a percentage of GDP, and Guerriero and Sen (2012) use the FDI inflows. Regardless of the measure employed, these studies show that financial globalization reduces the amount of income accruing to labor.

Finally, unionization and labor market institutions are also confounding factors that might influence the bargaining power of labor and, thus, its share of income. Elsby et al. (2013) claim that the impact of unions on the labor share is ambiguous; 
however, there is empirical evidence suggesting otherwise. Fichtenbaum (2009) finds that union density is positively related to the labor income share in the US manufacturing industry. Stockhammer (2017), focusing on OECD economies, obtains a similar positive relationship. Earlier studies on the determinants of labor income share also consider the effects of the size of government spending as a percentage of GDP. Stockhammer (2017) interprets this variable as a measure of welfare state, while Harrison (2005) and Jayadev (2007) treat it as a control for the importance of the government in the economy. An emerging consensus is that government spending tends to have a positive impact on labor share.

Lawrence (2015) uses data from the US manufacturing, mining and IT sectors to develop an alternative explanation for the decline in labor income share. His analysis suggests that the decreasing labor share in the USA is not due to the relative slower growth in wages. Instead, it is due to a combination of insufficient capital formation and labor-augmenting technology which leads to lower effective capital/ labor ratios. This increase in the supply of "effective labor," in turn, under gross complementarity between labor and capital in the sectors under consideration leads to lower labor shares.

This paper probes further into this literature that attempts to identify empirically the drivers of labor income shares focusing on the role of investment. We consider several of the control variables used in the most recent literature on the determination of labor income share, including workers' bargaining power and globalization. In addition, we consider the impact on labor shares of variables measuring a country's capital formation and R\&D expenses. Moreover, we do not only investigate the link between capital formation and labor income share covering more recent data, but also we seek to identify the magnitude of this relationship for varying levels of countries' income and economic freedom.

The rest of the paper is organized as follows. The subsequent section describes the empirical methods and specifications employed, the variables and data sources. Section 3 presents and discusses the estimation results, and, finally, Sect. 4 concludes.

\section{Data and empirical specifications}

This section describes the empirical strategy and the data used to identify the drivers of labor income share. The measurement of labor income share is subject to error because of difficulties in accurately measuring the income accruing to labor from self-employed activities (see, for example, Gollin 2002; Karabarbounis and Neiman 2014). The difficulties lie in fact that compensation from self-employment combines labor and capital income, and there is no accurate way to measure the exact amount accruing to each factor of production. To circumvent complications with the accurate measurement of self-employment wages, Karabarbounis and Neiman (2014) focus only on the part of income earned in the corporate sector. The ILO, which publishes a comprehensive dataset of countries' labor share, uses imputed selfemployed wages based on worker's common characteristics in order to account for this part of income. In this paper, we use the ILO measure for labor income share, which is available for the period 2004-2017. 
We further adjust the total labor income share by excluding compensation from the government following the method proposed by Stockhammer (2017). Thus, we obtain private labor income share for country $i$ in year $t$ (that is, $\operatorname{LS}_{i, t}^{p}$ ) using the following relationship $\mathrm{LS}_{i, t}^{p}=\left(\mathrm{LS}_{i, t}-\mathrm{GC}_{i, t}\right) /\left(1-\mathrm{GC}_{i, t}\right)$, where GC stands for government consumption. Karabarbounis and Neiman (2014) also do not account for the government labor share justifying that based on difficulties pinning down the optimization problem of the government's production function.

To obtain economically meaningful proxies for the impact of investment on countries' labor share, we need to control for the various factors that theoretically influence the amount of income accruing to labor. To ensure the comparability of our results and provide robust estimates for the impact of investment, we choose control variables for our empirical estimations drawn from existing literature (e.g., Stockhammer 2017; IMF 2007). Thus, we consider variables capturing globalization, both financial (FIN) and of the real economy (TRADE). Moreover, we include real GDP growth (GROWTH), technological change (ICT), human capital (HC), union density (UD) and the size of the welfare state (GC).

We use the following fixed-effects panel regression model as our baseline specification:

$$
\Delta \mathrm{LS}_{i, t}^{p}=\alpha_{1} \times \mathrm{INV}_{i, t}+\beta^{\prime} Z_{i, t}+\tau_{t}+\varepsilon_{i, t},
$$

where $i$ indicates the country and $t$ indicates the year. The constant $\tau_{t}$ captures the time-specific effects. The (log) of the initial value of private labor income share $\left(\mathrm{LS}_{i, t=0}^{p}\right)$, included in vector $Z$, captures the country-specific effects, since the initial differences in the private labor shares capture the differences in the time-invariant specific conditions of each country in the sample. Similar panel fixed-effects estimators that allow controlling for inter-country differences in labor income shares as well as time fixed effects are commonly used in related research (e.g., Jayadev 2007). Our dependent variable is growth of the natural logarithm of private labor income share, constructed following Stockhammer's (2017) approach. The variable INV stands for a country's gross fixed capital formation divided by its GDP, and $Z_{i, t}$ includes the set of control variables. As an alternative to using a country's gross fixed capital formation, we also use the part of it which captures only the expenditures on research and development R\&D.

In our baseline specification, the vector of control variables $Z_{i, t}$ includes the ratio of a country's total foreign assets and liabilities to its GDP as a proxy for the degree of international financial integration. We also use a country's total imports and exports relative to its output to proxy for the degree of a country's real integration with the world. To capture the effects of economic cycles, we include real GDP growth. We also include trade union density to control for workers' bargaining power and government consumption for the size of welfare state. We also include the human capital index to assess the role of human capital, and finally, we capture the impact of technological change on labor income shares by including the ratio of ICT capital as a percentage of GDP. Table 1 provides details about the construction and sources of the data. 
Table 1 Data description

\begin{tabular}{|c|c|}
\hline Variable & Definition \\
\hline Investment (INV) & $\begin{array}{l}\text { Gross capital formation at current PPPs as a percentage } \\
\text { of PPP collected from Penn World Tables } 9.0\end{array}$ \\
\hline Private labor share $\left(\mathrm{LS}^{p}\right)$ & $\begin{array}{l}\text { Labor income as a percentage of GDP. Data collected } \\
\text { from ILO SDG labor market indicators [10.4.1]. To } \\
\text { obtain private labor income share, we use Stockham- } \\
\text { mer's (2017) adjustment, described in the main body } \\
\text { of the text, and remove government consumption (GC) } \\
\text { from the total labor income share }\end{array}$ \\
\hline Government consumption (GC) & $\begin{array}{l}\text { We use the general government final consumption } \\
\text { expenditure as a percentage of GDP taken from the } \\
\text { World Bank collection of development indicators }\end{array}$ \\
\hline Real GDP growth (GROWTH) & $\begin{array}{l}\text { We use the real GDP growth (annual percentage rate) } \\
\text { collected from the IMF-IFS dataset }\end{array}$ \\
\hline Human capital index (HC) & $\begin{array}{l}\text { The human capital index taken from Penn World } \\
\text { Tables } 9.0\end{array}$ \\
\hline International financial integration (FIN) & $\begin{array}{l}\text { We use the sum of a country's total foreign assets } \\
\text { and liabilities as a percentage of its GDP using the } \\
\text { updated and extended version of dataset constructed } \\
\text { by Lane and Milesi-Ferretti (2007) }\end{array}$ \\
\hline Trade openness (TRADE) & $\begin{array}{l}\text { The sum of exports of goods and services and imports } \\
\text { of goods and services as a percentage of GDP taken } \\
\text { from the World Bank collection of development } \\
\text { indicators }\end{array}$ \\
\hline Union density (UD) & $\begin{array}{l}\text { Net union membership as a proportion of wage earn- } \\
\text { ers in employment. Data on union density rate are } \\
\text { obtained from Visser (2019) ICTWSS dataset }\end{array}$ \\
\hline ICT capital as a percentage of GDP (ICT) & $\begin{array}{l}\text { The share in ICT capital as a percentage of GDP taken } \\
\text { from the Conference Board Total Economy Database }\end{array}$ \\
\hline R\&D expenses as a percentage of GDP (R\&D) & $\begin{array}{l}\text { We use data for research and development expenditure } \\
\text { as a percentage of GDP collected from the World } \\
\text { Bank collection of development indicators. The source } \\
\text { is UNESCO Institute for Statistics }\end{array}$ \\
\hline Economic Freedom Index (FREE) & $\begin{array}{l}\text { We use either the index of economic freedom created by } \\
\text { the Heritage Foundation and The Wall Street Journal } \\
\text { or the Economic Freedom of the World index by } \\
\text { Frazer Institute }\end{array}$ \\
\hline
\end{tabular}

Table 2 reports descriptive statistics of the variables included in our baseline estimation. The sample of our baseline empirical specification includes 52 countries that we list in Table 7 of "Appendix". ${ }^{2}$ Our sample spans from 2004 to 2015 when the last data for international financial integration are available. The average of the private labor income share is about $43 \%$, and this value is significantly lower to the one reported in Stockhammer (2017) who uses data from 1970 to 2007. This finding also corroborates evidence for declining wage shares reported in several related studies

\footnotetext{
${ }^{2}$ Including the trade union density variable restricts our sample significantly as it is only available for 55 countries.
} 
Table 2 Descriptive statistics

\begin{tabular}{lrrrrl}
\hline & Mean & \multicolumn{1}{c}{ SD } & \multicolumn{1}{c}{ p25 } & Median & p75 \\
\hline LS $^{\mathrm{p}}$ & 43.24 & 8.96 & 37.69 & 43.97 & 50.05 \\
INV & 25.47 & 0.06 & 21.21 & 24.66 & 28.28 \\
FIN & 10.76 & 37.60 & 1.55 & 2.54 & 5.48 \\
TRADE & 103.06 & 73.44 & 58.11 & 79.04 & 127.92 \\
GROWTH & 2.96 & 3.69 & 1.40 & 2.85 & 5 \\
UD & 26.36 & 18.99 & 13.4 & 19.2 & 32 \\
GC & 17.71 & 4.22 & 14.53 & 18.45 & 20.25 \\
HC & 3.08 & 0.44 & 2.81 & 3.11 & 3.43 \\
ICT & 3.82 & 3.59 & 2.1 & 3 & 4.1 \\
\hline
\end{tabular}

The country-year observations in the baseline specification are 503 . $\mathrm{SD}$, the standard deviations of the variables, and p25 and p75 are the lower and higher quartiles, respectively; $\mathrm{LS}^{p}$, private labor income share; INV, gross capital formation at current PPPs as a percentage of PPP; FIN, a country's international financial integration; TRADE, country's trade openness; GROWTH, real GDP growth; UD, trade union density from Visser (2019); GC, general government final consumption expenditure as a percentage of GDP; HC, human capital index; ICT, country's ICT capital as a percentage of GDP. The description of the variables is given in Table 1

Table 3 Correlation between variables

\begin{tabular}{llllllllll}
\hline & LS $^{p}$ & INV & FIN & TRADE & GROWTH & UD & GC & HC & ICT \\
\hline LS $^{p}$ & 1 & & & & & & & & \\
INV & .022 & 1 & & & & & & & \\
FIN & 0.03 & 0.28 & 1 & & & & & & \\
TRADE & 0.02 & 0.22 & 0.47 & 1 & & & & & \\
GROWTH & -0.07 & 0.06 & -0.14 & -0.01 & 1 & & & & \\
UD & -0.04 & 0.15 & 0.43 & 0.14 & -0.10 & 1 & & & \\
GC & -0.04 & 0.16 & 0.25 & 0.11 & -0.21 & 0.45 & 1 & & \\
HC & -0.02 & 0.20 & 0.48 & 0.27 & -0.21 & 0.15 & 0.34 & 1 & \\
ICT & 0.01 & -0.01 & 0.05 & -0.06 & -0.11 & 0.08 & 0.16 & 0.01 & 1 \\
\hline
\end{tabular}

This table reports the cross-correlation between the variables included in the baseline regression

(see inter alia Karabarbounis and Neiman 2014; Stockhammer 2017; Guschanski and Özlem 2018). The average value of trade openness and government expenditure, on the other hand, appears to be much higher than that reported in Stockhammer (2017), while that of global financial integration is significantly lower. In Table 3, we report the cross-correlations between the variables included in the baseline estimation. All correlations reported are below 0.50 , and thus, our baseline estimation is not likely to face issues with multicollinearity.

Starting from the baseline empirical specification, we also investigate whether a country's level of income influences the magnitude of the relationship between investment and private labor income share. Particularly, we repeat the estimation of Eq. (1), excluding the union density variable in order to increase the sample size, but 
now we interact the investment variable (INV or R\&D) with income group dummies that we create based on the ILO's classification. The empirical specification now takes the following form:

$$
\Delta \mathrm{LS}_{i, t}^{p}=\sum_{c=1}^{4} a_{c} \times d_{c} \times \mathrm{INV}_{i, t}+\beta^{\prime} Z_{i, t}+\tau_{t}+\varepsilon_{i, t},
$$

where $d_{1(2,3,4)}$ is a $0-1$ dummy variables taking the value of 1 when ILO classifies a country as low- (lower-middle, upper-middle, high) income and zero otherwise.

Lastly, we investigate the extent to which investment/labor share relationship varies with the degree of a country's economic freedom. We expect that investment will lead to higher growth in labor income shares for countries with higher economic freedom. For robustness reasons, we use two alternative proxies for a country's economic freedom; the index created by the Heritage Foundation and The Wall Street Journal, as well as the Economic Freedom of the World index by Frazer Institute. We examine both the direct effects of economic freedom on labor income shares and also the effects of its interaction with investment. Particularly, we estimate the following equation:

$$
\Delta \mathrm{LS}_{i, t}^{p}=\alpha_{1} \times \mathrm{INV}_{i, t}+\gamma_{1} \times \mathrm{FREE}_{i, t}+\gamma_{2} \times \mathrm{FREE}_{i, t} \times \mathrm{INV}_{i, t}+\beta^{\prime} Z_{i, t}+\tau_{t}+\varepsilon_{i, t},
$$

where variable $\mathrm{FREE}_{i, t}$ stands for country's $i$ index of economic freedom for year $t$, measured either by the index of Heritage Foundation or that of Frazer Institute. To ease the interpretation, we standardize the economic freedom indexes to have 0 mean and standard deviation of 1 .

\section{Empirical results}

We report the results from the estimation of Eq. (1) in column (a) of Table 4. All variables included in the estimations are in natural logarithms. Before focusing on the effects of investment on labor share, we examine the relationship between the rest of the explanatory variables and the private labor income share growth. We find that higher foreign assets and liabilities as a percentage of GDP are associated with negative changes in private labor income shares. This result is consistent with theories supporting a negative relationship between globalization and labor income share, and comparable empirical results have been produced by Stockhammer (2017) who uses similar proxies for financial globalization. To further explore the validity of this finding, and that of the other explanatory variables, we repeat the estimation of Eq. (1), but now we exclude the variable union density. This allows larger sample sizes to be used as now several developing countries can be included in our estimations increasing the total sample to 99 countries. The strong negative relationship between financial globalization and labor share emerges also with the large sample, as we show in column (b) of Table 4.

The variable trade openness is not statistically significant in the empirical specification which includes the union density, but only in the one with the 99 
Table 4 Baseline specification

(a)

\begin{tabular}{llllll}
\hline Intercept & .007 & -.096 & Intercept & $\begin{array}{l}.070 \\
(1.56)\end{array}$ & $\begin{array}{l}.009^{* * *} \\
\text { INV }\end{array}$ \\
& $(0.10)$ & $(-1.25)$ & & $.60)$ \\
FIN & $.030^{* * *}$ & $.023^{*}$ & R\&D & .003 & $.009^{* *}$ \\
& $(2.79)$ & $(1.73)$ & & $(0.80)$ & $(2.60)$ \\
TRADE & $-.006^{* *}$ & $-.008^{* * *}$ & FIN & $-.005^{* *}$ & $-.008^{* * *}$ \\
& $(-2.12)$ & $(-3.06)$ & & $(-2.11)$ & $(-2.65)$ \\
GROWTH & .001 & $.010^{*}$ & TRADE & .002 & .007 \\
& $(0.31)$ & $(1.72)$ & & $(0.49)$ & $(1.50)$ \\
UD & -.003 & $-.004^{*}$ & GROWTH & -.002 & -.001 \\
& $(-1.43)$ & $(-1.94)$ & & $(-0.94)$ & $(-0.40)$ \\
GC & .002 & - & UD & .001 & - \\
& $(0.43)$ & & & $(0.16)$ & \\
HC & -.001 & $-.022^{*}$ & GC & -.006 & $-.029^{* *}$ \\
& $(-0.06)$ & $(-1.80)$ & & $(-0.50)$ & $(-1.97)$ \\
ICT & $.007 * *$ & .007 & HC & .003 & .006 \\
& $(1.96)$ & $(1.58)$ & & $(0.64)$ & $(1.37)$ \\
LS & $\left.-.005^{*}\right)$ & .004 & ICT & $-.008^{* * *}$ & -.001 \\
Countries/obs. & $(-1.86)$ & $(1.09)$ & & $(-2.57)$ & $(-0.49)$ \\
$R^{2}(\%)$ & $-.034^{* * *}$ & $-.015^{*}$ & LS & $-.028^{* *}$ & -.007 \\
\hline
\end{tabular}

This table shows the results from the estimation of Eq. (1). All variables are included in natural logarithms. All estimations include time fixed effects. The description of the variables included in the estimations is given in Table 1

$* / * * / * * *$ Significance at $90 \% / 95 \% / 99 \%$ confidence levels

countries, and the estimate takes a positive value, albeit only significant at the $10 \%$ confidence level. A similar, statistically weak, positive relationship is found in Stockhammer (2017) for low-income countries. A possible explanation for this result is given in IMF (2007) based upon the Stolper-Samuelson theorem. Based on this explanation, in developing economies trade openness is associated with higher wages for the low-skilled workers and lower wages for the high-skilled workers, reducing this way inequality.

From the estimation of our baseline specification, we also find a negative relationship between technological change and private labor income share, which, however, is only statistically significant at the $10 \%$ level of confidence. In the specification, however, which excludes the union density variable, we do not find any statistically significant relationship. Moreover, in our baseline specification we find that higher levels of human capital index are associated with higher private labor income share. On the contrary, for the larger sample this relationship is statistically insignificant, possibly pointing to a differential impact of human capital on higher- and lower-income countries' labor share. 
Finally, in contrast to most of the previous evidence, we find that government consumption affects adversely labor income share. However, this result holds only when we consider the sample with the 99 countries which includes more lowerincome countries. A negative relationship between government spending and labor income share is also reported by Stockhammer (2017) for the low-income countries. This counterintuitive negative relationship could be due to the downward adjustment of employment in response to the welfare state expansion, especially when substituting capital for labor is relatively easy (IMF 2007).

Turning now to investment-labor share nexus [columns (a) and (b) of Table 4], we find that the coefficient estimates of the impact of investment on labor share are positive and highly significant, at least for the baseline specification. This finding suggests that higher capital formation increases labor income share. When considering the larger sample, however, the coefficient estimate is again positive but only significant at the $10 \%$ level of confidence. We also examine the effects of countries' expenses on R\&D on their labor income share, and we report the results in columns (c) and (d) of Table 4. For the smaller sample of 52 countries, we do not find a significant relationship, while when we consider the larger sample, we do find a positive relationship. Including the R\&D expenses in the specification turns the estimate of human capital index statistically insignificant, as expected, since these expenses also include expenditures in higher education.

Table 5 The role of countries' level of income

\begin{tabular}{llll}
\hline & $(\mathrm{a})$ & & $(\mathrm{b})$ \\
\hline $\mathrm{INV} \times d_{\text {low }}$ & $.041^{* *}$ & $R \& D \times d_{\text {low }}$ & $\begin{array}{l}.014^{* *} \\
(2.48)\end{array}$ \\
& $(2.29)$ & & $.010^{* *}$ \\
$\mathrm{INV} \times d_{\text {low-mid }}$ & $.037^{* *}$ & $R \& D \times d_{\text {low-mid }}$ & $(2.36)$ \\
& $(2.21)$ & & $.009^{* *}$ \\
INV $\times d_{\text {upp-mid }}$ & $.034^{* *}$ & $R \& D \times d_{\text {upp-mid }}$ & $(2.37)$ \\
& $(2.10)$ & & $.009 * * *$ \\
INV $\times d_{\text {high }}$ & $.025^{*}$ & $R \& D \times d_{\text {high }}$ & $(2.66)$ \\
& $(1.84)$ & & 1.68 \\
$d_{\text {high }}-d_{\text {low }}$ & $2.98^{*}$ & $d_{\text {high }}-d_{\text {low }}$ & $(0.19)$ \\
$(p$ value $)$ & $(0.08)$ & $(p$ value $)$ & Yes \\
Control variables & Yes & Control variables & $-.117 * *$ \\
Intercept & -.104 & Intercept & $(-2.04)$ \\
& $(-1.37)$ & & $88 / 756$ \\
Countries/obs. & $99 / 1076$ & Countries/obs. & $5.03 \%$ \\
$R^{2}(\%)$ & $4.26 \%$ & $R^{2}(\%)$ & \\
\hline
\end{tabular}

This table shows the results from the estimation of Eq. (2) in the main body of the text. $d_{\text {low }}, d_{\text {low-mid }}, d_{\text {upp-mid }}$ and $d_{\text {high }}$ are 0-1 dummy variables taking the value of 1 for low-, lower-middle-, upper-middle-, and high-income countries and zero otherwise. Control variables in the estimations are FIN, TRADE, GROWTH, GC, $\mathrm{HC}$, ICT and $\mathrm{LS}_{i, t=0}^{p}$. We use the ILO's classification to identify the income level of a country. All variables, except for the dummy variables, are included in natural logarithms. The description of the variables included in the estimations is given in Table 1

$* / * * / * * *$ Significance at $90 \% / 95 \% / 99 \%$ confidence levels 
The model specification in Eq. (2) links the magnitude of the investment-labor share relationship with countries' level of income. We report the results from this estimation in Table 5. In column (a) we report the results for gross fixed capital formation as a percentage of GDP, and we find that the size of the positive reaction declines monotonically with increasing level of income. Particularly, for the highincome countries the estimate is only statistically significant at the $10 \%$ level of confidence. Additionally, the difference between the reaction of high- and low-income countries is statistically significant at the $10 \%$ level of significance. The level of a country's income, however, does not appear to be a significant driver of the magnitude of the relationship between labor income shares and R\&D expenses, as we show in column (b) of Table 5. Particularly, we find that R\&D expenses are equally significant for all income groups in our sample, and there is no statistical difference in the reaction estimates of the low- and high-income countries. So, for high-income countries it is mainly the expenses on research and development that can potentially increase private labor income shares and decrease inequality.

Finally, in Table 6 we report the results from the estimation of Eq. (3) which examines the role of economic freedom in the relationship between labor income shares and investment. In both specifications, with and without the union density

Table 6 The role of countries' level of economic freedom

\begin{tabular}{llllll}
\hline & \multicolumn{2}{l}{ Heritage foundation } & & \multicolumn{2}{l}{ Fraser Institute } \\
\cline { 2 - 3 } \cline { 5 - 6 } \cline { 5 - 6 } & $(\mathrm{a})$ & $(\mathrm{b})$ & & $(\mathrm{c})$ & $(\mathrm{d})$ \\
\hline INV & .018 & $.020^{* * *}$ & .020 & $.019 * *$ \\
& $(1.20)$ & $(2.70)$ & & $(1.27)$ & $(1.96)$ \\
FREE & $.038^{* *}$ & .022 & & $.048^{* *}$ & $.036^{* * *}$ \\
& $(2.38)$ & $(1.27)$ & & $(2.37)$ & $(2.62)$ \\
INV $\times$ FREE & $.027 * *$ & $.019 *$ & & $.036^{* * *}$ & $.025 * * *$ \\
& $(2.28)$ & $(1.94)$ & & $(2.89)$ & $(2.83)$ \\
Control variables & Yes & Yes & & Yes & Yes \\
Intercept & -.035 & -.037 & & .029 & $-.136 * * *$ \\
& $(-1.09)$ & $(-1.09)$ & & $(0.40)$ & $(-3.21)$ \\
Countries/obs. & $49 / 474$ & $83 / 902$ & $49 / 471$ & $86 / 921$ \\
$R^{2}(\%)$ & $13.29 \%$ & $5.44 \%$ & & $14.11 \%$ & $7.82 \%$ \\
\hline
\end{tabular}

This table shows the results from the estimation of Eq. (3) in the main body of the text. The variable FREE measures a country's degree of economic freedom measured either by the index of the Heritage Foundation or that of the Fraser Institute and is standardized to have mean 0 and standard deviation 1 . The specifications in columns (a) and (c) include the union density (UD) variable, while those reported in columns (b) and (d) not. Both indexes of economic freedom are not available for all countries for the 2004-2015 period, and, thus, the sample size is different to the one employed for the estimations in Table 4. The rest of the control variables in the estimations are FIN, TRADE, GROWTH, GC, HC, ICT and $\mathrm{LS}_{i, t=0}^{p}$. All variables, except for the dummy variables, are included in natural logarithms. The description of the variables included in the estimations is given in Table 1 
variable, and for both economic freedom indexes, we find that economic freedom amplifies the positive effect of gross fixed capital formation on labor income share, as the interaction terms are positive and statistically significant. In the specifications with the union density level, we also find that economic freedom is associated with higher labor shares.

\section{Conclusion}

In this paper, we pursue an exploratory empirical exercise on the determinants of the functional distribution of income for the period 2004-2015, with a focus on the effects of capital formation and R\&D expenses. We employ a panel fixedeffects framework to investigate the impact that investment and other theoretically motivated control variables have on labor income shares for a broad cross section of countries. We consider a sample of 99 countries, which reduces to 52 when we include the trade union membership in our specification, due to data availability.

We find a positive relationship between higher gross fixed capital formation (and R\&D expenses) as a percentage of GDP and labor income share. This evidence is in line with the predictions of the theoretical mechanism for the role of investment in labor share proposed by Lawrence (2015). In addition, we find that fixed capital formation has larger distributional effects in lower-income countries. R\&D expenses, on the other hand, are equally important for all countries, regardless of income levels. In addition, we provide evidence showing that the labor share enhancing effects of capital formation increase with a country's degree of economic freedom. Economic freedom amplifies the positive effect of gross fixed capital formation on labor income shares.

Open Access This article is licensed under a Creative Commons Attribution 4.0 International License, which permits use, sharing, adaptation, distribution and reproduction in any medium or format, as long as you give appropriate credit to the original author(s) and the source, provide a link to the Creative Commons licence, and indicate if changes were made. The images or other third party material in this article are included in the article's Creative Commons licence, unless indicated otherwise in a credit line to the material. If material is not included in the article's Creative Commons licence and your intended use is not permitted by statutory regulation or exceeds the permitted use, you will need to obtain permission directly from the copyright holder. To view a copy of this licence, visit http://creativecommons.org/licen ses/by/4.0/.

\section{Appendix}

See Table 7. 
Table 7 Countries in our sample

\begin{tabular}{|c|c|c|c|}
\hline \multicolumn{2}{|c|}{ The group of 52 countries includes } & \multicolumn{2}{|c|}{ The group of 99 countries also includes } \\
\hline Argentina & Latvia & Albania & Mali \\
\hline Austria & Lithuania & Algeria & Mongolia \\
\hline Belgium & Luxembourg & Angola & Mozambique \\
\hline Bulgaria & Malaysia & Armenia & Niger \\
\hline Canada & Malta & Bahrain & Nigeria \\
\hline Chile & Mexico & Bangladesh & Pakistan \\
\hline China & Netherlands & Barbados & Peru \\
\hline Hong Kong & New Zealand & Bolivia & Qatar \\
\hline Colombia & Norway & Burkina Faso & Moldova \\
\hline Costa Rica & Philippines & Cambodia & Saudi Arabia \\
\hline Croatia & Poland & Cameroon & Serbia \\
\hline Cyprus & Portugal & Cote d'Ivoire & Sri Lanka \\
\hline Czech Republic & South Korea & Dominican Republic & Sudan \\
\hline Denmark & Romania & Ecuador & Syria \\
\hline Estonia & Russia & Egypt & Tajikistan \\
\hline Finland & Singapore & Ghana & Thailand \\
\hline France & Slovakia & Guatemala & Tunisia \\
\hline Germany & Slovenia & Iran & Uganda \\
\hline Greece & South Africa & Iraq & Ukraine \\
\hline Hungary & Spain & Jamaica & United Arab Emirates \\
\hline Iceland & Sweden & Jordan & \\
\hline India & Switzerland & Kazakhstan & \\
\hline Indonesia & Turkey & Kenya & \\
\hline Ireland & UK & Kuwait & \\
\hline Israel & USA & Kyrgyzstan & \\
\hline Italy & & Madagascar & \\
\hline Japan & & Malawi & \\
\hline
\end{tabular}

\section{References}

Atkinson AB (2009) Factor shares: the principal problem of political economy? Oxford Review of Economic Policy 25(1):3-16

Dünhaupt P (2017) Determinants of labor's income share in the era of financialisation. Camb J Econ 41(1):283-306

Elsby MWL, Hobijn B, Sahin A (2013) The decline of the U.S. labor share. Brooking papers on economic activity, Fall $p p$ 1-2

Fichtenbaum R (2009) The impact of unions on labor's share of income: a time-series analysis. Rev Polit Econ 21:567-588

Furceri D, Loungani P (2018) The distributional effects of capital account liberalization. J Dev Econ 130:127-144

Gollin D (2002) Getting income shares right. J Polit Econ 110:458-474

Guerriero M, Sen K (2012) What determines the share of labor in national income? A cross-country analysis. IZA discussion papers 6643, Institute of Labor Economics 
Guschanski A, Özlem O (2018) Determinants of the wage share: a cross-country comparison using sectoral data. CESifo Forum 19:44-54

Harrison, A. (2005). Has globalization Eroded labor's share? Some cross-country evidence. MPRA working paper 39649

IMF (2007) The globalization of labor. Chapter 5 of world economic outlook. IMF, Washington

Jacobson M, Occhino F (2012) Labor's decline share of income and rising inequality. Economic commentary, Federal Reserve Bank of Cleveland

Jayadev A (2007) Capital account openness and the labor share of income. Camb J Econ 31:423-443

Kaldor N (1957) A model of economic growth. Econ J 67(268):591-624

Karabarbounis L, Neiman B (2014) The global decline of the labor share. Quart J Econ 129:61-103

Lane PR, Milesi-Ferretti GM (2007) The external wealth of nations mark II: revised and extended estimates of foreign assets and liabilities, 1970-2004. J Int Econ 73:223-250

Lawrence RZ (2015) Recent declines in labor's share in US income: a preliminary neoclassical account. NBER working paper 21296

Piketty T (2014) Capital in the twenty-first century. Harvard University Press, Cambridge

Stockhammer E (2017) Determinants of the wage share: a panel analysis of advanced and developing economies. Br J Ind Relat 55:3-33

Visser J (2019) ICTWSS database. version 6.0. Amsterdam Institute for Advanced Labor Studies (AIAS), University of Amsterdam, Amsterdam

Publisher's Note Springer Nature remains neutral with regard to jurisdictional claims in published maps and institutional affiliations. 